\title{
Application of Mutant ap3 Allele-based Markers for the Selection of the Long- lasting Flower Phenotype (Misome-shō) in Evergreen Azalea Cultivars
}

\author{
Yu Gobara ${ }^{1}$, Kyeong-Seong Cheon ${ }^{2}$, Akira Nakatsuka ${ }^{3}$ and Nobuo Kobayashi ${ }^{3 *}$ \\ ${ }^{1}$ United graduate School of Agricultural Science, Tottori University, Tottori 680-8553, Japan \\ ${ }^{2}$ Department of Forest Bio-Resource, National Institute of Forest Science, Suwon 16631, Republic of Korea \\ ${ }^{3}$ Faculty of Life and Environmental Science, Shimane University, Matsue, 690-8504, Japan
}

There is a long-lasting flower trait with a temporal color change, known as "misome-shō", in Japanese evergreen azalea. This trait has been found in several wild Japanese evergreen azalea species, such as Rhododendron kaempferi 'Nikkō-misome', R. macrosepalum 'Kochō-zoroi', R. indicum 'Chōjyu-hō', and $R$. × hannoense 'Amagi-beni-chōjyu'. The corollas of long-lasting flower cultivars undergo a conversion of normal corollas to sepaloid corollas due to loss of function of the MADS-box B class gene, APETALA3 (AP3) homolog. Also, the long-lasting flower trait was shown to be recessive to normal flowers and controlled by a single gene. To develop a DNA marker for selection of the long-lasting flower phenotype, we carried out a multiplex-PCR approach to detect the ap3 mutant allele related to long-lasting flower traits, and investigated the flower phenotypes in crossed progenies of 23 cross combinations and 245 individuals. The normal flower phenotype individuals in the crossed progenies were homozygous for the normal allele or heterozygous for the normal allele and the ap3 mutant allele. On the other hand, the long-lasting flower phenotype individuals in the crossed progenies were homozygous for the ap 3 mutant allele of long-lasting cultivars. These results support the idea that the long-lasting flower trait is caused by a mutation in the AP3 homolog, and it has been newly clarified that any combination of these mutant alleles in long-lasting flower cultivars has the long-lasting flower phenotype. In conclusion, our data indicate that efficient selection of individuals with long-lasting flowers will be possible by using selection DNA markers linked to the long-lasting flower trait.

Key Words: $A P 3$, breeding, MADS-box gene, marker assisted selection, mutant allele.

\section{Introduction}

Among the 50 Rhododendron species native to Japan (Kurashige et al., 1998), species within the subgenus Tsutsusi, section Tsutsusi, such as R. kaempferi, R. indicum, R. kiusianum, R. ripense, and R. macrosepalum, are important genetic resources for the evergreen azaleas used as ornamental shrubs or pot azaleas (Kobayashi, 2020). Each cultivar group, such as Edo Kirishima, Kurume, Ryūkyū, Hirado, and Satsuki, has been developed since the Edo era (1603-1867) by selection and crossing based on these wild species as they have high ornamental value, are easy to cultivate,

Received; April 16, 2021. Accepted; July 9, 2021.

First Published Online in J-STAGE on September 17, 2021.

This research was supported by Grant-in-Aid for Scientific Research (KAKENHI No. 18K05617) from Japan Society for the Promotion of Science (JSPS).

* Corresponding author (E-mail: nkobayashi@life.shimane-u.ac.jp). and exhibit interspecific hybridization (Kobayashi et al., 2000; Kurashige and Kobayashi, 2008; Kobayashi, 2016). During the azalea boom in the middle of the $17^{\text {th }}$ century, cultivars with flower color variations and shape mutants, such as white flowers, double flowers, and hose-in-hose flowers, were selected and collected from wild species all over the country. Many of these cultivars were described in the first monograph on azaleas, "Kinshū - makura", edited in 1692 (Ito and Creech, 1984; Kobayashi, 2016). This monograph provided the first description of 'Misome-guruma', a cultivar with small light-red flowers, long stamens, and a long blooming season, with the flowers turning greenish in June (Ito and Creech, 1984). The long-lasting flower trait, known as "misome-shō", has been found in several wild species, such as R. kaempferi 'Nikkōmisome', R. macrosepalum 'Kochō-zoroi', R. indicum 'Chōjyu-hō', and $R$. × hannoense 'Amagi-beni-chōjyu'.

In order to select breeding material for long-lasting flower cultivars, we have conducted various studies on 
floral morphology, inheritance, and a MADS-box B class gene related to floral morphology. In a previous morphological study, we indicated that the long-lasting flower trait is a floral homeotic mutant with a sepaloid corolla (Kobayashi et al., 2010; Gobara et al., 2017). In addition, the long-lasting flower trait was shown to be a recessive trait of the normal flower phenotype and is controlled by a single gene (Gobara et al., 2017). Therefore, it takes a long-term breeding cycle to develop long-lasting flowers with new flower traits, such as double flowers and hose-in-hose flowers.

A marker-associated selection (MAS) (Xu and Crouch, 2008) system is important for rapid selection of the long-lasting flower phenotype, which is a recessive trait, during the juvenile period. In long-lasting cultivars, transcription of the AP3 homolog was reduced, and a long terminal repeat retrotransposon was independently inserted into exons 1,2 , and 7 or an unknown sequence in exon 1 of the gDNA of each cultivar. This insertion apparently abolished the normal mRNA sequence of the AP3 homolog (Cheon et al., 2018). Based on this insertion, DNA markers for the detection of the ap 3 mutant allele were developed for each longlasting cultivar. In a previous study (Cheon et al., 2018), normal flower phenotypes of the $F_{1}$ progenies between normal and long-lasting cultivars were heterozygous for the normal and ap3 mutant alleles. In addition, it was shown that long-lasting flowers in crossed progenies between normal and long-lasting cultivars were homozygous for the ap 3 mutant allele in one cross combination.

In this study, to develop a rapid selection marker for the long-lasting flower phenotype in evergreen azaleas, we carried out a multiplex-PCR approach to detect the ap3 mutant allele related to the long-lasting flower trait in crossed progenies of various cross combinations using the DNA markers described by Cheon et al. (2018).

\section{Materials and Methods}

\section{Plant materials}

The normal flower azaleas R.kaempferi, R. macrosepalum, R. indicum 'Ōsakazuki', R. ripense, $R . \times$ pulchrum 'Ōmurasaki', and Kurume azalea 'Wakakaede', and the long-lasting flower cultivars R. kaempferi 'Nikkō-misome', R. macrosepalum 'Kochō-zoroi', R. indicum 'Chōjyu-hō', and $R . \times$ hannoense 'Amagi-beni-chōjyu' were used. A total of $69 \mathrm{~F}_{1}$ progenies from 11 cross combinations between normal and long-lasting cultivars and a total of $25 \mathrm{~F}_{1}$ progenies of six cross combinations between longlasting cultivars were used (Table 1). In addition, a total of 151 crossed progenies of six cross combinations between the $F_{1}$ hybrids of normal and long-lasting cultivars were used (Table 2). These plants were obtained from the azalea resource collection at the Plant Breeding Laboratory of the Faculty of Life and
Environmental Sciences, Shimane University.

\section{DNA marker analysis}

Genomic DNA was extracted from the leaves of each plant using the modified CTAB method (Kobayashi et al., 1998). The multiplex-PCR primers described by Cheon et al. (2018) that can distinguish each ap3 mutant allele in long-lasting cultivars are shown in Table 3 and Figure 1A. The Pr2 and Pr8 primers, which were newly designed from the $A P 3$ homolog sequences of R. kaempferi 'Nikkō-misome' (rkap3-NM, DDBJ Acc. No. AB861605) and $R . \times$ hannoense 'Amagi-benichōjyu' (rhap3-AC, DDBJ Acc. No. AB861608), were used in this study. The three PCR primers Pr8, Pr9, and Pr10 were designed to amplify approximately $425 \mathrm{bp}$ fragments in 'Nikkō-misome', and approximately $180 \mathrm{bp}$ fragments in cultivars other than 'Nikkōmisome'. The three PCR primers $\operatorname{Pr} 1, \operatorname{Pr} 3$, and $\operatorname{Pr} 4$ were designed to amplify approximately $315 \mathrm{bp}$ fragments in 'Kochō-zoroi' (rmap3-KZ, DDBJ Acc. No. AB861606), and approximately $180 \mathrm{bp}$ fragments in cultivars other than 'Kochō-zoroi'. The three PCR primers $\operatorname{Pr} 5, \operatorname{Pr} 6$, and $\operatorname{Pr} 7$ were designed to amplify approximately $600 \mathrm{bp}$ fragments in 'Chōjyu-hō' (riap3$\mathrm{CH}$, DDBJ Acc. No. AB861607), and approximately $220 \mathrm{bp}$ fragments in cultivars other than 'Chōjyu-hō'. The three PCR primers $\operatorname{Pr} 1, \operatorname{Pr} 2$, and $\operatorname{Pr} 3$ were designed to amplify approximately $500 \mathrm{bp}$ fragments in 'Amagibeni-chōjyu', and approximately $180 \mathrm{bp}$ fragment in cultivars other than 'Amagi-beni-chōjyu'. A multiplexPCR was performed with the primer set in Table 3 to detect the ap 3 mutant alleles of each long-lasting cultivar and the normal alleles of normal flowers as the insets in rmap3-KZ and rhap3- $A C$ were located in exon 1. The normal alleles, rmap3-KZ, and rhap3-AC were detected using four primers, $\operatorname{Pr} 1, \operatorname{Pr} 2, \operatorname{Pr} 3$, and $\operatorname{Pr} 4$. The multiplex-PCR was performed in $10 \mu \mathrm{L}$ reaction mixtures containing $10 \mathrm{ng}$ DNA template, $1 \times$ Ex-Taq buffer, $200 \mu \mathrm{M}$ dNTPs, $0.25 \mathrm{U}$ Ex-Taq (TaKaRa Bio Inc., Shiga, Japan), and $0.2 \mu \mathrm{M}$ of each primer. The reaction conditions were as follows: denaturation at $94^{\circ} \mathrm{C}$ for $3 \mathrm{~min} ; 35$ cycles of denaturation at $94^{\circ} \mathrm{C}$ for $30 \mathrm{~s}$, annealing at $61^{\circ} \mathrm{C}$ for $30 \mathrm{~s}$, extension at $72^{\circ} \mathrm{C}$ for $30 \mathrm{~s}$, and a final extension at $72^{\circ} \mathrm{C}$ for $2 \mathrm{~min}$. The amplified PCR products were analyzed by electrophoresis in a 1.5\% agarose gel (Nippon Genetics Co., Ltd., Tokyo, Japan) using $0.5 \times$ TBE buffer and run at $100 \mathrm{~V}$ for $30 \mathrm{~min}$. When using the Pr2 and Pr9 primers, the annealing temperature was changed to $56^{\circ} \mathrm{C}$. The crossed progenies between the $\mathrm{F}_{1}$ hybrids of normal and long-lasting cultivars had their genotypes determined using the DNA markers before blooming. We investigated the flower phenotypes of the crossed progenies that bloomed from 2013 to 2020 and identified genotypes of the AP3 homolog through the multiplex-PCR. 
Table 1. PCR amplification profiles for the ap 3 mutant alleles and the flower phenotypes in $\mathrm{F}_{1}$ progenies.

\begin{tabular}{|c|c|c|c|c|c|}
\hline \multirow{2}{*}{ Line } & \multicolumn{3}{|c|}{ Parents } & \multirow{2}{*}{ Phenotype $^{\mathrm{z}}$} & \multirow{2}{*}{ Genotype $^{y}$} \\
\hline & Seed & $\times$ & Pollen & & \\
\hline & \multicolumn{3}{|l|}{ R. macrosepalum 'Kochō-zoroi' } & $\mathrm{L}$ & rmap3-KZ/rmap3-KZ \\
\hline & \multicolumn{3}{|l|}{ R. indicum 'Chōjyu-hō' } & $\mathrm{L}$ & riap3-CH/riap3- $\mathrm{CH}$ \\
\hline & \multicolumn{3}{|l|}{ R. $\times$ hannoense 'Amagi-beni-chōjyu' } & $\mathrm{L}$ & rhap3-AC/rhap3-AC \\
\hline & \multicolumn{3}{|c|}{ Hybrid 'Tenkō' $(R . \times$ hannoense 'Amagi-beni-chōjyu' $\times R$. kaempferi 'Nikkō-misome') } & $\mathrm{L}$ & rkap3-NM/rhap3-AC \\
\hline & \multicolumn{3}{|c|}{ Kurume azalea 'Wakakaede' } & $\mathrm{N}$ & $A P 3 / A P 3$ \\
\hline & \multicolumn{3}{|l|}{ Kurume azalea 'Kirin' } & $\mathrm{N}$ & $A P 3 / A P 3$ \\
\hline & \multicolumn{3}{|l|}{ R. oldhamii } & $\mathrm{N}$ & $A P 3 / A P 3$ \\
\hline & \multicolumn{3}{|l|}{ R. × pulchrum 'Ōmurasaki' } & $\mathrm{N}$ & $A P 3 / A P 3$ \\
\hline & \multicolumn{3}{|l|}{ R. ripense } & $\mathrm{N}$ & $A P 3 / A P 3$ \\
\hline & \multicolumn{3}{|l|}{ R. kiusianum } & $\mathrm{N}$ & $A P 3 / A P 3$ \\
\hline & \multicolumn{3}{|c|}{ Hybrid 'Tō-sei' ( $R$. transiens 'Hatsusimo' $\times$ pot azalea 'Star light') } & $\mathrm{N}$ & $A P 3 / A P 3$ \\
\hline & Long-lasting flower-type & & Normal flower-type & & \\
\hline 06012 & R. kaempferi 'Nikkō-misome' & $x$ & Kurume azalea 'Wakakaede' & $\mathrm{N}(14)$ & AP3/rkap3-NM \\
\hline 07097 & R. indicum 'Chōjyu-hō' & $\times$ & Kurume azalea 'Kirin' & $\mathrm{N}(4)$ & AP3/riap3-CH \\
\hline 06025 & R. indicum 'Chōjyu-hō' & $\times$ & R. oldhamii & $\mathrm{N}(3)$ & AP3/riap3-CH \\
\hline 99088 & R. $\times$ hannoense 'Amagi-beni-chōjyu' & $x$ & R. × pulchrum 'Ōmurasaki' & $\mathrm{N}(5)$ & $A P 3 /$ rhap3-AC \\
\hline 05216 & R. $\times$ hannoense 'Amagi-beni-chōjyu' & $x$ & Kurume azalea 'Kirin' & $\mathrm{N}(4)$ & $A P 3 /$ rhap3-AC \\
\hline 99094 & R. $\times$ hannoense 'Amagi-beni-chōjyu' & $x$ & R. ripense & $\mathrm{N}(4)$ & $A P 3 /$ rhap3-AC \\
\hline \multirow[t]{3}{*}{04093} & \multirow[t]{2}{*}{ Hybrid 'Tenkō' } & \multirow[t]{2}{*}{$x$} & \multirow[t]{2}{*}{ R. × pulchrum 'Ōmurasaki' } & $\mathrm{N}(6)$ & $A P 3 /$ rhap3-AC \\
\hline & & & & $\mathrm{N}(6)$ & AP3/rkap3-NM \\
\hline & Normal flower-type & & Long-lasting flower-type & & \\
\hline 05063 & Kurume azalea 'Wakakaede' & $x$ & R. indicum 'Chōjyu-hō' & $\mathrm{N}(10)$ & AP3/riap3-CH \\
\hline 04171 & R. oldhamii & $x$ & R. macrosepalum 'Kochō-zoroi' & $\mathrm{N}(3)$ & AP3/rmap3-KZ \\
\hline 99090 & R. kiusianum & $\times$ & R. $\times$ hannoense 'Amagi-beni-chōjyu' & $\mathrm{N}(2)$ & $A P 3 /$ rhap3-AC \\
\hline \multirow[t]{3}{*}{04083} & \multirow[t]{2}{*}{ Hybrid 'Tō-sei' } & \multirow[t]{2}{*}{$x$} & \multirow[t]{2}{*}{ Hybrid 'Tenkō' } & $\mathrm{N}(2)$ & $A P 3 /$ rhap3-AC \\
\hline & & & & $\mathrm{N}(6)$ & AP3/rkap3-NM \\
\hline & Long-lasting flower-type & & Long-lasting flower-type & & \\
\hline 06032 & R. kaempferi 'Nikkō-misome' & $x$ & R. indicum 'Chōjyu-hō' & $\mathrm{L}(3)$ & rkap3-NM/riap3-CH \\
\hline 06021 & R. indicum 'Chōjyu-hō' & $x$ & R. kaempferi 'Nikkō-misome' & $\mathrm{L}(2)$ & rkap3-NM/riap3-CH \\
\hline 06027 & R. macrosepalum 'Kochō-zoroi' & $x$ & R. kaempferi 'Nikkō-misome' & $\mathrm{L}(2)$ & rkap3-NM/rmap3-KZ \\
\hline 06019 & R. $\times$ hannoense 'Amagi-beni-chōjyu' & $x$ & R. kaempferi 'Nikkō-misome' & $\mathrm{L}(9)$ & rkap3-NM/rhap3-AC \\
\hline 05067 & R. $\times$ hannoense 'Amagi-beni-chōjyu' & $x$ & R. indicum 'Chōjyu-hō' & $\mathrm{L}(7)$ & riap3-CH/rhap3-AC \\
\hline 98051 & R. $\times$ hannoense 'Amagi-beni-chōjyu' & $x$ & R. macrosepalum 'Kochō-zoroi' & $\mathrm{L}(2)$ & rmap3-KZ/rhap3-AC \\
\hline
\end{tabular}

${ }^{z} \mathrm{~N}$ : normal flower phenotype. L: long-lasting flower phenotype. Parentheses show the individual number.

${ }^{y}$ Genotype was based on the multiplex-PCR products, which were rkap3-NM (425 bp); rmap3-KZ (315 bp); riap3-CH (600 bp); and rhap3-AC (500 bp) as shown in the mutant allele. AP3 shows the normal allele.

\section{Results}

Detection of the ap 3 mutant allele in long-lasting cultivars

The PCR products obtained using the three primers (Pr8, Pr9, and Pr10) amplified approximately $425 \mathrm{bp}$ fragments in 'Nikkō-misome', and approximately $180 \mathrm{bp}$ fragments in the other cultivars (Fig. 1B). The PCR products obtained using the primers Pr5, Pr6, and Pr7 amplified approximately $600 \mathrm{bp}$ fragments in 'Chōjyu-hō', and approximately 220 bp fragments in cultivars other than 'Chōjyu-hō' (Fig. 1B). The PCR products obtained using the four primers $\operatorname{Pr} 1, \operatorname{Pr} 2, \operatorname{Pr} 3$, and Pr4 amplified approximately $315 \mathrm{bp}$ fragments in
'Kochō-zoroi', 500 bp fragments in 'Amagi-benichōjyu', and $180 \mathrm{bp}$ fragments in cultivars other than these (Fig. 1B).

Detection of the ap 3 mutant allele in crossed progenies

All analyzed $F_{1}$ progenies between the normal and long-lasting cultivars had normal flower phenotypes and were heterozygous for the ap 3 mutant allele and the normal allele (Table 1; Fig. 1C). On the other hand, all analyzed $F_{1}$ progenies between the long-lasting cultivars had long-lasting flower phenotypes and were homozygous for the ap3 mutant alleles (Table 1; Fig. 1D).

In the crossed progenies between the $\mathrm{F}_{1}$ hybrids of 
Table 2. PCR amplification profiles for the ap 3 mutant alleles and the flower phenotypes in the crossed progenies between $\mathrm{F}_{1}$ hybrids of normal and long-lasting cultivars.

\begin{tabular}{|c|c|c|c|c|c|}
\hline \multirow{2}{*}{ Line } & \multicolumn{3}{|c|}{ Parents (allele/allele) } & \multirow{2}{*}{ Phenotype $^{z}$} & \multirow{2}{*}{ Genotype ${ }^{y}$} \\
\hline & Seed & $\times$ & Pollen & & \\
\hline \multirow{4}{*}{13003} & \multirow{4}{*}{ 04093-5 (AP3/rkap3-NM) } & \multirow{4}{*}{$x$} & \multirow{4}{*}{ 05216-1 (AP3/rhap3-AC) } & $\mathrm{N}(6)$ & $A P 3 / A P 3$ \\
\hline & & & & $\mathrm{N}(3)$ & AP3/rkap3-NM \\
\hline & & & & $\mathrm{N}(3)$ & AP3/rhap3-AC \\
\hline & & & & L (3) & rkap3-NM/rhap3-AC \\
\hline \multirow{4}{*}{13006} & \multirow{4}{*}{ 04093-5 (AP3/rkap3-NM) } & \multirow{4}{*}{$x$} & \multirow{4}{*}{ 07097-1 (AP3/riap3-CH) } & $\mathrm{N}(9)$ & $A P 3 / A P 3$ \\
\hline & & & & $\mathrm{N}(9)$ & AP3/rkap3-NM \\
\hline & & & & $\mathrm{N}(9)$ & AP3/riap3-CH \\
\hline & & & & $\mathrm{L}(7)$ & rkap3-NM/riap3-CH \\
\hline \multirow{4}{*}{13013} & \multirow{4}{*}{ 04093-5 (AP3/rkap3-NM) } & \multirow{4}{*}{$x$} & \multirow{4}{*}{ 06025-1 (AP3/riap3-CH) } & $\mathrm{N}(2)$ & $A P 3 / A P 3$ \\
\hline & & & & $N(7)$ & AP3/rkap3-NM \\
\hline & & & & $\mathrm{N}(7)$ & AP3/riap3-CH \\
\hline & & & & L (3) & rkap3-NM/riap3-CH \\
\hline \multirow{4}{*}{13016} & \multirow{4}{*}{ 04171-1 (AP3/rmap3-KZ) } & \multirow{4}{*}{$x$} & \multirow{4}{*}{ 07097-1 (AP3/riap3-CH) } & $\mathrm{N}(10)$ & $A P 3 / A P 3$ \\
\hline & & & & $\mathrm{N}(9)$ & AP3/rmap $3-K Z$ \\
\hline & & & & $\mathrm{N}(7)$ & AP3/riap3-CH \\
\hline & & & & $\mathrm{L}(7)$ & rmap3-KZ/riap3-CH \\
\hline \multirow{4}{*}{13018} & \multirow{4}{*}{ 04171-1 (AP3/rmap3-KZ) } & \multirow{4}{*}{$x$} & \multirow{4}{*}{ 05216-1 (AP3/rhap3-AC) } & $\mathrm{N}(8)$ & $A P 3 / A P 3$ \\
\hline & & & & $\mathrm{N}(8)$ & AP3/rmap $3-K Z$ \\
\hline & & & & $\mathrm{N}(5)$ & $A P 3 /$ rhap $3-A C$ \\
\hline & & & & $\mathrm{L}(6)$ & rmap3-KZ/rhap3-AC \\
\hline \multirow{4}{*}{13020} & \multirow{4}{*}{ 06025-1 (AP3/riap3-CH) } & \multirow{4}{*}{$x$} & \multirow{4}{*}{ 05216-1 (AP3/rhap3-AC) } & $\mathrm{N}(5)$ & $A P 3 / A P 3$ \\
\hline & & & & $\mathrm{N}(8)$ & AP3/riap3-CH \\
\hline & & & & $\mathrm{N}(5)$ & $A P 3 /$ rhap3-AC \\
\hline & & & & $\mathrm{L}(5)$ & riap3-CH/rhap3-AC \\
\hline
\end{tabular}

z N: normal flower phenotype. L: long-lasting flower phenotype. Parentheses show the individual number.

${ }^{y}$ Genotype was based on multiplex-PCR products, which were rkap3-NM (425 bp); rmap3-KZ (315 bp); riap3-CH(600 bp); and rhap3-AC (500 bp) as shown in the mutant allele. $A P 3$ shows the normal allele.

Table 3. Primers used for the multiplex-PCR analysis.

\begin{tabular}{|c|c|c|c|c|}
\hline Detecting gene & No. & Name & Sequence $\left(5^{\prime}-3^{\prime}\right)$ & Reference \\
\hline \multirow{3}{*}{ rhap3-AC ('Amagi-beni-chōjyu') } & $\operatorname{Pr} 1$ & AP3-AMAGI (MAR) F1 & GAGAGTGAAGAAATGGCGAG & Cheon et al., 2018 \\
\hline & $\operatorname{Pr} 2$ & AP3 AMA-R1 & CTTCAACTTTAAGTATTTATAGGC & developed in this study \\
\hline & $\operatorname{Pr} 3$ & 5RACE-AP3-2 & GTATTCATGGAGCTTCTCGG & Cheon et al., 2018 \\
\hline \multirow{3}{*}{ rmap3-KZ ('Kochō-zoroi') } & $\operatorname{Pr} 1$ & AP3-AMAGI (MAR) F1 & GAGAGTGAAGAAATGGCGAG & Cheon et al., 2018 \\
\hline & $\operatorname{Pr} 3$ & 5RACE-AP3-2 & GTATTCATGGAGCTTCTCGG & Cheon et al., 2018 \\
\hline & Pr4 & AP3-KOCHO (MAR) R & GGATAACGCCTCTAGAAGGG & Cheon et al., 2018 \\
\hline \multirow{3}{*}{ riap3-CH ('Chōjyu-hō') } & $\operatorname{Pr} 5$ & AP3-CHOJYU (MAR) F1 & GCGAATACCTAGAACGAAGCA & Cheon et al., 2018 \\
\hline & $\operatorname{Pr} 6$ & AP3-CHOJYU (MAR) R1 & ATGGAGGAGCGTGGATTAAA & Cheon et al., 2018 \\
\hline & $\operatorname{Pr} 7$ & AP3-CHOJYU (MAR) R2 & GGGACCGATACCGCTATTTA & Cheon et al., 2018 \\
\hline \multirow{3}{*}{ rkap3-NM ('Nikkō-misome') } & $\operatorname{Pr} 8$ & AP3-NIKKO (MAR) F1 & ATAGAACGCAATTGGAGAGGA & developed in this study \\
\hline & $\operatorname{Pr} 9$ & AP3 AMA-R1 & CTTCAACTTTAAGTATTTATAGGC & same with primer 2 \\
\hline & $\operatorname{Pr} 10$ & AP3-NIKKO (MAR) R1 & AAGCAAATGTCGTGAGATCG & Cheon et al., 2018 \\
\hline
\end{tabular}

normal and long-lasting cultivars, normal and longlasting flower phenotypes exhibited an approximately 3:1 split (Table 2; Fig. 3A). In all combinations of the crossed progenies between the $\mathrm{F}_{1}$ hybrids of normal and long-lasting cultivars, normal alleles were detected in normal flower phenotypes, and homozygous ap3 mutant alleles were detected in the long-lasting flower phenotypes (Table 2; Fig. 2). The genotype segregation pattern in the crossed progenies between the $F_{1}$ hybrids of the normal and long-lasting cultivars, identified by the multiplex-PCR, corresponded to the expected ratio (Table 4). 
A

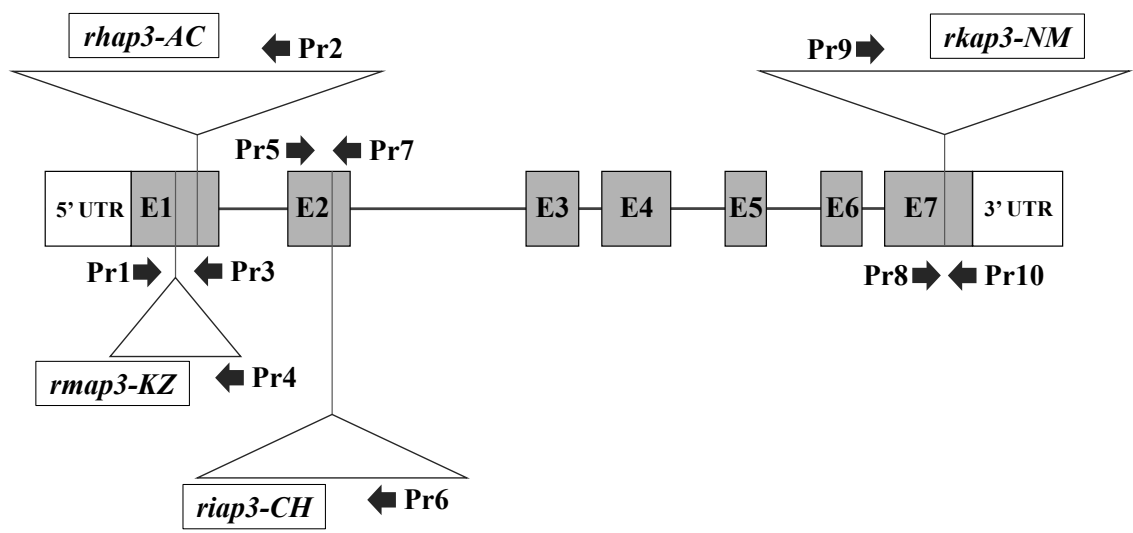

B

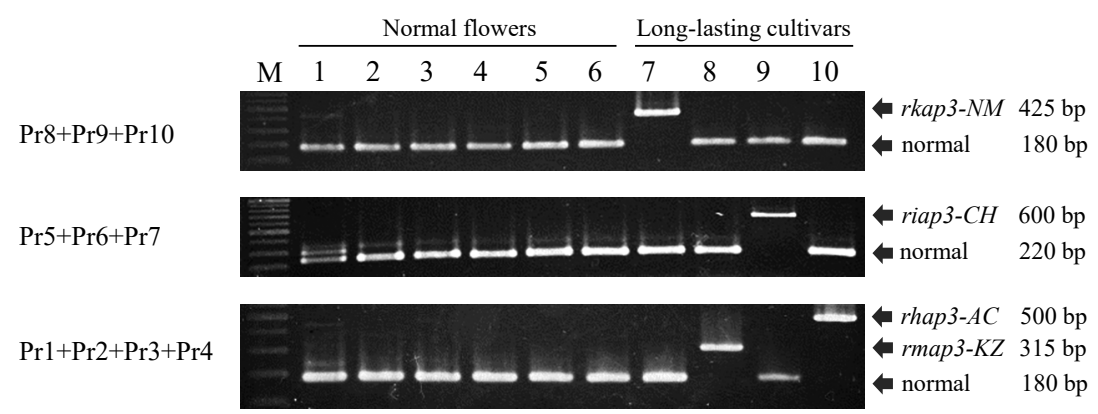

C

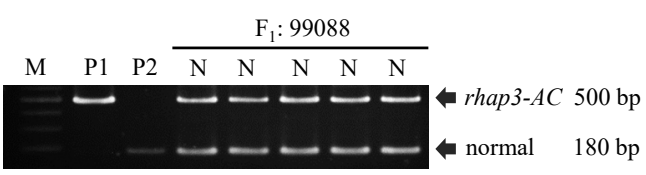

D

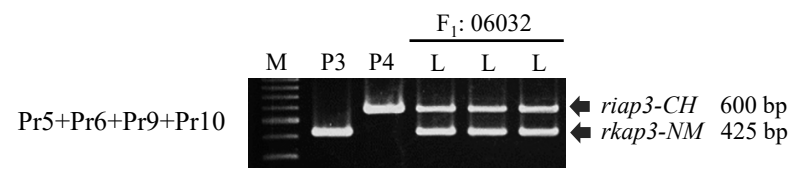

Fig. 1. Multiplex-PCR to detect the normal $A P 3$ allele linked to the normal flower phenotype and the ap 3 mutant allele linked to the long-lasting flower phenotype..A: Schematic diagram showing the primer regions that distinguish normal and ap3 mutant alleles (Cheon et al., 2018). E1-7 and lines indicate each exon and each intron, respectively. Horizontal arrows indicate regions and direction of primers. B: Results of multiplex-PCR amplification of the normal allele and rkap3-NM, riap3-CH, rmap3-KZ, and rhap3-AC. Numbers indicate (1) Rhododendron kaempferi, (2) R. macrosepalum, (3) R. indicum 'Ōsakazuki', (4) R. ripense, (5) R. × pulchrum 'Ōmurasaki' (6) Kurume azalea 'Wakakaede', (7) R. kaempferi 'Nikkō-misome', (8) R. macrosepalum 'Kochō-zoroi', (9) R. indicum 'Chōjyu-hō', and (10) R. $\times$ hannoense 'Amagi-benichōjyu'. C: Results of multiplex-PCR amplifications in 99088 line $(\mathrm{P} 1: R . \times$ hannoense 'Amagi-beni-chōjyu' $\times \mathrm{P} 2: R . \times$ pulchrum 'Ōmurasaki'). D: Results of the multiplex-PCR amplifications in 06032 line (P3: R. kaempferi 'Nikkō-misome' $\times$ P4: R. indicum 'Chōjyuhō'). $\mathrm{N}$ and $\mathrm{L}$ indicate the normal flower phenotype and the long-lasting flower phenotype, respectively. $\mathrm{M}$ indicates a $100 \mathrm{bp}$ ladder (Nippon Genetics).

\section{Discussion}

The vase life of flowers is one of the most important characteristics required by consumers (Imanishi et al., 1992). Normal flowering azalea plants finish flowering in about two weeks. In contrast, long-lasting flower cultivars keep their corollas for more than 100 days, with the flowers then turning greenish (Kobayashi, 2013).
This is similar to the "autumn-like color" of hydrangeas, in which flowering continues with changes in the flower color (Yoshida et al., 2008).

The corollas of long-lasting flower cultivars involves the conversion of normal corollas to sepaloid corollas due to loss of function of the AP3 homolog (Cheon et al., 2018). In addition, the long-lasting flower trait was shown to be recessive to normal flowers and con- 
13006

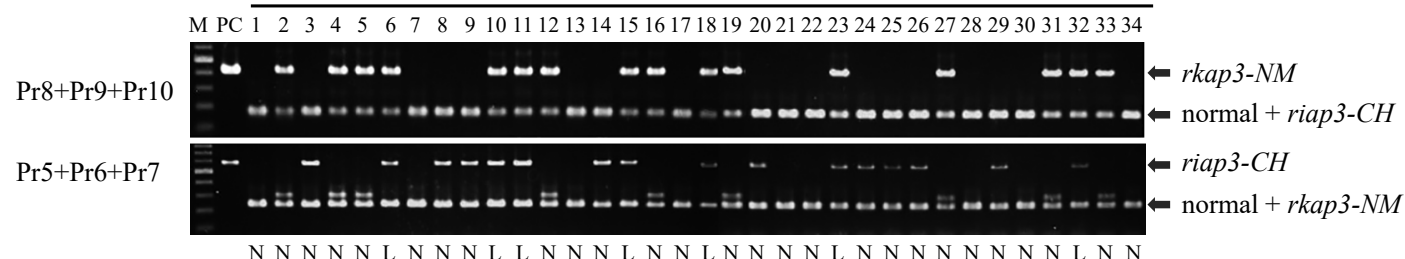

N N N N N L N N N L L N N N L N N L N N N N L N N N N N N N N L N N

Fig. 2. Results of the multiplex-PCR amplifications in the 13006 line $(04093 \times 07097)$. $\mathrm{N}$ and $\mathrm{L}$ indicate the normal flower phenotype and the long-lasting flower phenotype, respectively. PC indicates the positive control ( $\operatorname{Pr} 8+\operatorname{Pr} 9+\operatorname{Pr} 10$ : 'Nikkō-misome'; Pr5 + Pr6 + Pr7: 'Chōjyuhō'). M indicates a 100 bp ladder (Nippon Genetics).

A

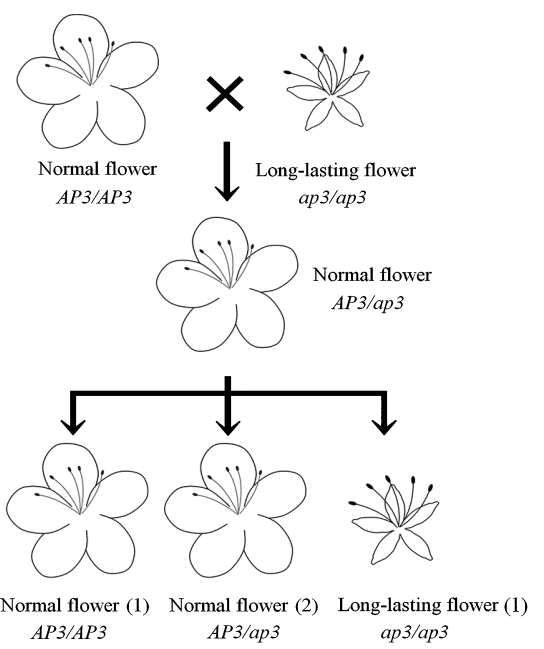

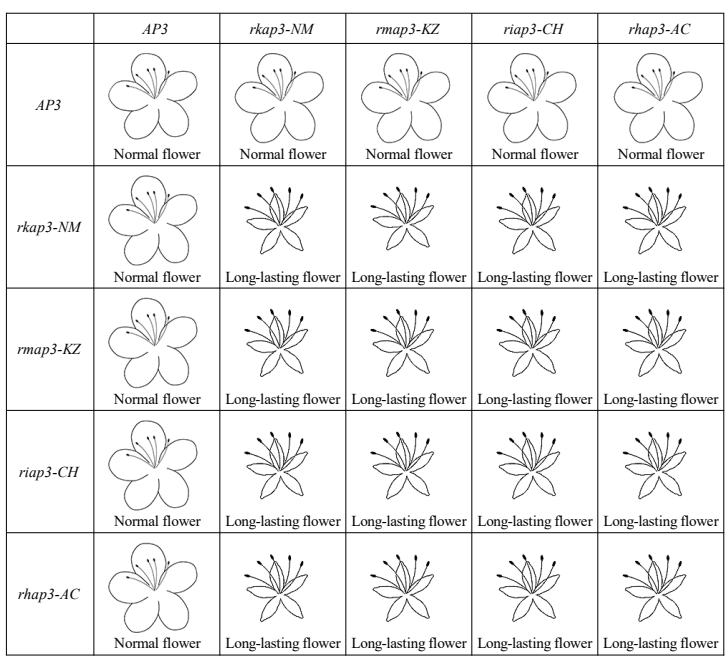

Fig. 3. The relationships between flower phenotypes and genotypes in crossed progenies of long-lasting cultivars derived from the four different species. A: The inheritance model of the long-lasting flower trait. Parentheses show the segregation ratio. B: The inheritance model of the flower phenotypes based on the $A P 3$ genotype combinations.

Table 4. Segregation data for the ap 3 mutant alleles in the crossed progenies between $F_{1}$ hybrids of normal and long-lasting cultivars.

\begin{tabular}{|c|c|c|c|c|c|c|c|c|c|c|c|c|}
\hline \multirow[b]{2}{*}{ Line } & \multicolumn{3}{|c|}{ Parents } & \multirow[b]{2}{*}{$\begin{array}{c}\text { No. of } \\
\text { progenies }\end{array}$} & \multicolumn{3}{|c|}{ Genotypic segregation } & \multicolumn{3}{|c|}{ Expected ratio } & \multirow[b]{2}{*}{$\chi^{2}$} & \multirow[b]{2}{*}{$\mathrm{P}$} \\
\hline & Seed & $x$ & Pollen & & $\begin{array}{l}\text { Homozygous } \\
\text { normal allele }\end{array}$ & $\begin{array}{c}\text { Normal allele } \\
\text { and mutant } \\
\text { allele }\end{array}$ & $\begin{array}{l}\text { Homozygous } \\
\text { mutant allele }\end{array}$ & $\begin{array}{l}\text { Homozygous } \\
\text { normal allele }\end{array}$ & $\begin{array}{c}\text { Normal allele } \\
\text { and mutant } \\
\text { allele }\end{array}$ & $\begin{array}{l}\text { Homozygous } \\
\text { mutant allele }\end{array}$ & & \\
\hline 13003 & 04093 & $x$ & 05216 & 15 & 6 & 6 & 3 & 1 & 2 & 1 & 1.800 & 0.407 \\
\hline 13006 & 04093 & $x$ & 07097 & 34 & 9 & 18 & 7 & 1 & 2 & 1 & 0.353 & 0.838 \\
\hline 13013 & 04093 & $x$ & 06025 & 19 & 2 & 14 & 3 & 1 & 2 & 1 & 4.368 & 0.113 \\
\hline 13016 & 04171 & $x$ & 07097 & 33 & 10 & 16 & 7 & 1 & 2 & 1 & 0.576 & 0.750 \\
\hline 13018 & 04171 & $x$ & 05216 & 27 & 8 & 13 & 6 & 1 & 2 & 1 & 0.333 & 0.846 \\
\hline 13020 & 06025 & $\times$ & 05216 & 23 & 5 & 13 & 5 & 1 & 2 & 1 & 0.391 & 0.822 \\
\hline
\end{tabular}

trolled by a single gene (Gobara et al., 2017). Similar mutations of sepaloid petals have been found in other plants, and Singh et al. (2014) suggested that the development of sepaloid petals in Papaver somniferum was caused by the reduced expression of PapsAP3-1; this trait is a recessive trait controlled by a single gene. In herbaceous peony (Paeonia lactiflora), a spontaneous corolla mutant under natural conditions was closely associated with selective expression alterations of duplicated AP3 and PI genes; down-regulation of dupli- cated B class genes may result in a reduction in the AP3-PI heterodimer in sepaloid corollas (Gong et al., 2017). Additionally, Lange et al. (2013) suggested that sepaloid petal development in Eschscholzia californica was caused by a lack of function of the MADS-box B class gene, EScaGLO. DNA markers related to flower shape mutation have been developed for doubleflowered cultivars caused by mutations of the MADSbox C class gene AGAMOUS in gentians (Gentiana scabra) (Tasaki et al., 2017) and Matthiola incana 
(Nakatsuka and Koishi, 2018). However, there are no reports of any DNA markers related to an improvement in the ornamental value and vase life of flowers caused by $\mathrm{B}$ class gene mutations such as the long-lasting flower trait in azalea.

The long-lasting flower trait in azalea is commercially important, and we have been conducting studies on breeding materials (Kobayashi, 2020). In a previous study, DNA markers to detect the ap3 mutant allele were developed in long-lasting cultivars (Cheon et al., 2018). In this study, we used a multiplex-PCR approach to detect the ap3 mutant allele related to the longlasting flower trait in normal flowers and long-lasting flower cultivars, and crossed progenies of 23 crosscombinations and 245 individuals using the DNA markers described by Cheon et al. (2018). As a result of the multiplex-PCR, we found normal flowers were homozygous for the AP3 gene, and each long-lasting cultivar had a homozygous ap3 mutant allele (Fig. 1B). In all cross combinations, individuals with the normal flower phenotype were homozygous for the normal allele or heterozygous for the normal allele and the ap 3 mutant allele (Tables 1 and 2). On the other hand, the $F_{1}$ progenies between long-lasting cultivars and longlasting flower phenotype individuals in the cross progenies between $F_{1}$ hybrids of normal and long-lasting flower cultivars were homozygous for the ap 3 mutant allele derived from different species of the long-lasting cultivars (Tables 1 and 2).

The genotype that was detected before blooming by using the DNA markers was linked to the flower phenotype in all crossed progenies. The reliability of the DNA markers for long-lasting flower trait selection was confirmed in this study. Figure 3 shows the relationship between flower phenotypes and genotypes in crossed progenies of long-lasting cultivars derived from the four different species clarified in this report. It was revealed that all of the ap 3 mutant alleles in each longlasting flower cultivar were recessive to normal alleles (Fig. 3B). There was no dominant/recessive relationship between the ap 3 mutant alleles of each long-lasting flower cultivar derived from the four different species, and we confirmed that any combination of these mutant alleles had a long-lasting flower phenotype (Fig. 3B). These results strengthen the concept that the longlasting flower trait is caused by a mutation in the $A P 3$ homolog. These results also suggest the possibility of breeding new azalea cultivars with the characteristics of multiple species by interspecific crossing using longlasting cultivars, rather than simply through varietal crossing.

We have been conducting various studies on the morphological mutations found in evergreen azalea cultivars such as hose-in-hose, double-flowers, narrowpetals, and narrow-leaf mutations, to apply them in our breeding program (Kobayashi, 2016). In previous studies, we reported the development of DNA markers to select hose-in-hose cultivars (Cheon et al., 2017a), and the genetic analysis of the double-flowered trait (Cheon et al., 2017b) and narrow-petal and -leaf mutations (Tasaki et al., 2019). We are selecting the long-lasting flower phenotype during the juvenile period using these MAS systems. Among the selected individuals, candidates for new long-lasting flower cultivars have been developed.

In conclusion, interspecific crossing using the longlasting flower trait that is present across species can contribute to the development of new long-lasting cultivars with high ornamental value. In addition, it was shown that an efficient selection process for longlasting individuals is possible by using selection DNA markers linked to the long-lasting flower trait.

\section{Acknowledgements}

The authors thank the faculty of Life and Environmental Sciences of Shimane University for financial support in publishing this report.

\section{Literature Cited}

Cheon, K. S., A. Nakatsuka, Y. Gobara and N. Kobayashi. 2017a. Mutant RoPI-1 allele-based marker development for selection of the hose-in-hose flower phenotype in Rhododendron obtusum cultivars. Euphytica 213: 3. DOI: 10.1007/s10681016-1808-x.

Cheon, K. S., A. Nakatsuka, K. Tasaki and N. Kobayashi. 2017b. Floral morphology and MADS gene expression in doubleflowered Japanese evergreen azalea. Hort. J. 86: 269-276.

Cheon, K. S., A. Nakatsuka, K. Tasaki and N. Kobayashi. 2018. Long-lasting corolla cultivars in Japanese azaleas: a mutant $A P 3 / D E F$ homolog identified in traditional azalea cultivars from more than 300 years ago. Front. Plant Sci. 8: 2239. DOI: $10.3389 /$ fpls.2017.02239.

Gobara, Y., A. Nakatsuka, K. S. Cheon and N. Kobayashi. 2017. Floral morphology and inheritance of the long-lasting flower trait (misome-sho) in Japanese evergreen azalea cultivars. Hort. Res. (Japan) 16: 383-390 (In Japanese with English abstract).

Gong, P., X. Ao, G. Liu, F. Cheng and C. He. 2017. Duplication and whorl-specific down-regulation of the obligate AP3-PI heterodimer genes explain the origin of Paeonia lactiflora plants with spontaneous corolla mutation. Plant Cell Physiol. 58: 411-425.

Imanishi, H., F. Yonezawa and H. Imanishi. 1992. Psychological research on the attitude of florist customers towards flowers. J. Japan. Soc. Hort. Sci. 60: 981-987 (In Japanese with English abstract).

Ito, I. and J. L. Creech. 1984. A Brocade Pillow: Azaleas of Old Japan. John Weatherhill, Inc., New York and Tokyo.

Kobayashi, N. 2013. Evaluation and application of evergreen azalea resources of Japan. Acta Hortic. 990: 213-219.

Kobayashi, N. 2016. Tsutsuji. p. 151-180. In: M. Shibata (ed.). Hana no hinshu kairyou no nihonshi (In Japanese). Bunkyō, Tokyo.

Kobayashi, N. 2020. Japanese azalea germplasm; the living horticulture properties. Acta Hortic. 1291: 163-168.

Kobayashi, N., T. Handa, Y. Yoshimura, Y. Tsumura, K. Arisumi and K. Takayanagi. 2000. Evidence for introgressive hybridization based on chloroplast DNA polymorphisms and morphological variation in wild evergreen azalea popula- 
tions of the Kirishima mountains, Japan. Edinb. J. Bot. 57: 209-219.

Kobayashi, N., T. Horikoshi, H. Katsuyama, T. Handa and K. Takayanagi. 1998. A simple and efficient DNA extraction method for plants, especially woody plants. Plant Tissue Cult. Biotechnol. 4: 76-79.

Kobayashi, N., M. Ishihara, M. Ohtani, K. S. Cheon, D. Mizuta, K. Tasaki and A. Nakatsuka. 2010. Evaluation and application of the long-lasting flower trait (misome-sho) of azalea cultivars. Acta Hortic. 855: 165-168.

Kurashige, Y. and N. Kobayashi. 2008. Evergreen azalea cultivars and breeding trends in the Taisho era inferred by discovered "azalea research notes" of Kanagawa agricultural research station. Hort. Res. (Japan) 7: 323-328 (In Japanese with English abstract).

Kurashige, Y., M. Mine, N. Kobayashi, T. Handa, K. Takayanagi and T. Yukawa. 1998. Investigation of sectional relationships in the genus Rhododendron (Ericaceae) based on mat $\mathrm{K}$ sequences. J. Jap. Bot. 73: 143-154.

Lange, M., S. Orashakova, S. Lange, R. Melzer, G. Theißen, D. R. Smyth and A. Becker. 2013. The seirena B class floral homeotic mutant of California Poppy (Eschscholzia californica) reveals a function of the enigmatic PI motif in the formation of specific multimeric MADS domain protein complexes. Plant Cell 25: 438-453.
Nakatsuka, T. and K. Koishi. 2018. Molecular characterization of a double-flower mutation in Matthiola incana. Plant Sci. 268: 39-46.

Singh, S. K., A. K. Shukla, O. P. Dhawan and A. K. Shasany. 2014. Recessive loci $P p s-1$ and $O M$ differentially regulate PISTILLATA-1 and APETALA3-1 expression for sepal and petal development in Papaver somniferum. PloS One 9: e101272. DOI: 10.1371/journal.pone.0101272.

Tasaki, K., A. Higuchi, K. Fujita, A. Watanabe, N. Sasaki, K. Fujiwara, H. Abe, Z. Naito, R. Takahashi, T. Hikage and M. Nishihara. 2017. Development of molecular markers for breeding of double flowers in Japanese gentian. Mol. Breed. 37: 33. DOI: 10.1007/s11032-017-0633-9.

Tasaki, K., A. Nakatsuka, K. S. Cheon and N. Kobayashi. 2019. Genetic demonstration of the involvement of WUSCHELrelated homeobox $(W O X)$ genes in narrow-petal and narrowleaf mutations in traditional Japanese azalea cultivars. Euphytica 215: 5. DOI: 10.1007/s10681-018-2323-z.

$\mathrm{Xu}, \mathrm{Y}$. and J. H. Crouch. 2008. Marker-assisted selection in plant breeding: from publications to practice. Crop Sci. 48: 391407.

Yoshida, K., D. Ito, Y. Shinkai and T. Kondo. 2008. Change of color and components in sepals of chameleon hydrangea during maturation and senescence. Phytochemistry 69: 3159-3165. 